Digitalizacja archiwalnych numerów czasopisma naukowego Analecta Cracoviensia 1-24 (1969-1992)

i ich publikacja w otwartym dostępie - zadanie finansowane w ramach umowy 672/P-DUN/2017 ze środków

Ministra Nauki i Szkolnictwa Wyższego przeznaczonych na działalność upowszechniającą naukę

\title{
RELIGIJNOŚĆ AMBIWALENTNA A POTRZEBY I WARTOŚCI
}

Religijność jest uniwersalnym ludzkim doświadczeniem transcendentnego wymiaru rzeczywistości. Jej istotę stanowi jednostkowe, osobiste odniesienie do rzeczywistości transcendentnej (Sacrum, Najwyższa Wartość, Bóg) i religijnego systemu, który pośredniczy w nawiązaniu relacji z tą rzeczywistością.

W zajęciu indywidualnego stanowiska wobec rzeczywistości transcendentnej bierze udział cała ludzka osoba wraz z jej psychicznymi właściwościami: rozumem, sferą uczuć, wolą i działaniem. W myśli chrześcijańskiej o tym stosunku mówi się w kategoriach osobowych jako o wierze, niewierze i wątpieniu. Psychologia religii natomiast traktuje te odniesienia jako postawę religijną o wartości dodatniej, ujemnej (postawa negatywna) i niezdecydowanej lub obojętnej. Zwraca ona też uwagę na to, że psychologiczna warstwa religijnego odniesienia jednostki jest determinowana strukturą jej osobowości i jej funkcjonowaniem w kontekście społeczno-kulturowym. Wiara w Boga bowiem, rozpatrywana jako religijna postawa, czy — inaczej mówiąc - jako religijność jest także funkcją podmiotowych, psychologicznych uwarunkowań. Przybiera ona różny kształt oraz stopień intensywności rozciągający się na psychologicznym kontinuum: od intensywnego i pełnego treściowo stosunku pozytywnego, poprzez stosunek niezdecydowany czy obojętny, aż do całkowicie negatywnego.

W psychologii religii zwykło się poświęcać wiele miejsca postawie religijnej akceptacji Boga i postawie ateistycznej, w ich różnych aspektach i stopniach. Stosunkowo mało natomiast analizuje się religijność ludzi, których stosunek do nadprzyrodzoności posiada charakter względnie trwałego niezdecydowania, sceptyzmu, wątpienia. Badania religijności wykazują, że niezdecydowanie takie jest stosunkowo częstym zjawiskiem. Przejawia się ono w okresach zwątpienia, trwałych stanach ciągłego poszukiwania czy też w niemożności podjęcia decyzji i dokonania wyboru na rzecz religijnego zaangażowania lub odrzucenia przedmiotu religijnego. 


\section{POJĘCIE AMBIWALENCJI W PSYCHOLOGII}

A mbiwa le n c j a etymologicznie oznacza dwuwartościowość, dwojakość (łac. ambo - oba + valens - znaczący). Pojęciem tym określa się stan przeżywania stanów uczuciowych (np. wstrętu i pociągu, nienawiści i miłości) w stosunku do tych samych osób, przedmiotów lub sytuacji.

W psychologii pojęciem tym posługuje się głównie orientacja psychoanalityczna. Wprowadził je E. Bleuler początkowo na określenie wewnętrznego rozszczepienia, rozłamu w osobowości tak u schizofreników jak i u osób normalnych, utrudniającego a nawet uniemożliwiającego dokonanie wyboru na rzecz osób czy sytuacji. Złożoność tego konfliktu i jego nasilenie zwiększają się, pisał Bleuler, gdy włączą się inne siły, jak np. seksualność, które ze swej natury oprócz wystarczająco silnego czynnika pozytywnego zawierają także czynnik negatywny prawie tak samo silny (obawy, wstyd, zahamowanie), których jednostka nie potrafi zharmonizować.

Przez ambiwalencję Bleuler rozumiał również wszystkie różnice między dwoma dynamicznymi systemami w osobowości, które nie mogą się scalić i które manifestują się jako przeciwstawne. Jedne z nich są rządzone przez kontrolną instancję osobowości - wolę, a inne przez system instynktów źle zintegrowany, który zużywa dla siebie część życia umysłowego i uczuciowego jednostki. Walka motywów, między wyższym piętrem osobowości a zmiennym — niższym, zamkniętym w podświadomości na skutek thumienia, ujawnia się przez pewne symptomy w warstwie somatycznej. Tak np. uczucie miłości do byłego partnera osadzone w podświadomości, manifestować się może na jego widok nawet po zerwaniu z nim i nawiązaniu nowej relacji z kimś innym, w postaci bladości, suchości w gardle, pulsowania serca nawet wówczas, gdy nie czuje się już z nim związany. Ambiwalencja ujawnia się szczególnie podczas przymusowych myśli lub czynności, gdy np. ktoś podczas czynności modlitewnej ma przymus wymyślania brzydkich słów a nawet ich wypowiadania. Każdy z nas zresztą, posiada ambiwalentne uczucia wobec sytuacji i ludzi, którzy z pewnych względów wzbudzają w nas uczucia przyjemne, a z innych nieprzyjemne ${ }^{1}$.

Z. Freud był zdania, że termin ambiwalencja należy stosować na określenie wszelkiego rodzaju postaw konfliktowych. Wg niego ambiwalencja u jednostki jest powtórzeniem ambiwalencji bardziej fundamentalnej, ujawniającej się w kompleksie Edypa. Jednostka wynosi ją z przeżywania przeciwstawnych uczuć miłości i nienawiści do każdego z rodziców.

Laplanche i Pontalis oprócz uczuć miłości i nienawiści włączają w pojęcie ambiwalencji także inne przeciwstawne tendencje, postawy i uczucia wy-

' G. Cruchon, Ambivalences dans le comportement religieux, „Nouvelle Revue Theologique" 91: 1969 s. 300; L. S ch le g e 1, Grundriss der Tiefenpsychologie, t. 3, München 1978, s. 32. 
stępujące jednocześnie w odniesieniu do jednego i tego samego obiektu².

H. G. Grabner rozumie ambiwalencję nieco inaczej niż Bleuler i Freud, a mianowicie jako poszerzenie świata przeżyć $w$ ich biegunowe odpowiedniki typu przyjemność i przykrość, podmiot i przedmiot, aktywność i bierność. Źródłem ambiwalencji jest wg niego doświadczenie tzw. pra-ambiwalencji przy opuszczaniu matczynego łona i pierwszym zetknięciu się z obcym sobie światem zewnętrznym podczas narodzin. Ambiwalencja ma miejsce wówczas, gdy jednostka pożąda obiektów w tej mierze, w jakiej mogą jej one zaoferować namiastkę utraconego stanu $\mathrm{z}$ matczynego łona, a $\mathrm{z}$ drugiej strony odrzuca ona te same obiekty ponownie, ponieważ nie okazują się wystarczającymi, by w pełni zaspokoić pragnienie powrotu do raju sprzed narodzin ${ }^{3}$.

$\mathrm{Z}$ ambiwalencją wiąże się poczucie niepewności i wątpienia. Wg E. H. Eriksona wątpienie bierze początek w drugim stadium psychospołecznego rozwoju, zwanym stadium analno-mięśniowym. Wtedy na bazie rozwiniętej autoekspresji i samokontroli utrwala się w dziecku poczucie pewności, życzliwość i zdolność wyboru (autonomia). Nadmierne zawstydzenie dziecka przez otoczenie prowadzi je do utraty poczucia samokontroli oraz trwałego poczucia wstydu i niepewności.

Cnotą, która się pojawia w tym stadium, jest wola. Źródłem jej rozwoju są: ćwiczenie się w uporze i przykłady silnej woli, demonstrowanej przez innych. Jest ona niezbędna, aby dziecko potrafiło stopniowo zaakceptować prawa i konieczności. Elementy woli rozwijają się stopniowo dzięki doświadczeniom angażującym świadomość i uwagę, manipulację, werbalizację i lokomocję. Wola jest rozwijającą się ciągle zdolnością dokonywania swobodnych wyborów, podejmowania decyzji, ćwiczenia się w powściągliwości i wytrwałego działania ${ }^{4}$.

K. Dąbrowski w swej teorii dezintegracji pozytywnej posługuje się pojęciami ambiwalencji i ambitendencji. Są to dynamizmy odpowiedzialne za dezintegrację na niskim jeszcze poziomie rozwoju osobowości. Ambiwalencja jest wyrazem jednoczesnego uczucia sympatii i braku sympatii, zbliżania się i oddalania, poczucia niższości i wyższości, miłości i nienawiści. Uwyraźnia się we fluktuacji nastrojów, naprzemiennym pobudzaniu i hamowaniu. Ambitendencja natomiast jest niespójnym, niekonsekwentnym zachowaniem, przejawiającym się w zmiennych i konfliktowych działaniach, braku decyzji chcenia i nie chcenia dwu rzeczy nie do pogodzenia naraz. Charakteryzuje ona postępowanie przegranych ${ }^{5}$.

Podsumowując, można powiedzieć, że a mbiwale n cja jest to stan psychiczny jednostki, cechujący się równoczesnym występowaniem pozytywnych

${ }^{2}$ G. Cruchon, jw., s. 300.

${ }^{3}$ L. Schlegel, jw., s. 37.

${ }^{4}$ C. S. Hall, G. Lind z e y, Teorie osobowości, Warszawa 1990, s. 93 - 94.

${ }^{5}$ K. D ą brows k i, Funkcje i struktura emocjonalna osobowości, Lublin 1984, s. 54 - 55. 
i negatywnych stanów emocjonalnych w stosunku do tego samego przedmiotu, tzn. osób, sytuacji, itp. Stan ten wyraża się poczuciem niepewności, niezdecydowania, nieufności, podejrzliwości, nieokreśloności. Towarzyszyć może mu stan zwątpienia, kwestionowania czegoś, podawania w wątpliwość (np. istnienia Boga), poczucia niezdecydowania, niemożności dokonania wyboru i określenia siebie w stosunku do obiektu. Współwystępują też z ambiwalencją niespójne zachowania polegające na podejmowaniu działań zmierzających do wzajemnie wykluczających się celów, najczęściej przy braku uświadomienia sobie sprzeczności. Ambiwalencjia obniża więc sprawność myślenia i działania a w swojej ostrzejszej formie utrudnia bądź nawet uniemożliwia podjęcie decyzji. Zwątpienie jest rodzajem konfliktu między tendencjami do akceptowania i nieakceptowania twierdzeń czy między tendencjami do przypisywania i odmawiania jakiemuś zjawisku realnego istnienia ${ }^{6}$.

\section{RELIGIJNOSĆ AMBIWALENTNA}

Zwątpienie w religijności jest zjawiskiem dość zwyczajnym, gdyż wiele ludzi przynajmniej od czasu do czasu cierpi z jego powodu. Na jego występowanie wpływa także przenikający dzisiejszą kulturę klimat zwątpienia i negacji. W religijności dodatkowym źródłem wątpienia jest obiektywna niepewność istnienia kresu religijnego odniesienia (postawy). To sprawia, że jednostka waha się, zanim się zaangażuje. Wątpliwości znikają dopiero w samym akcie wiary, jako sposobie odczuwania zaufania do przedmiotu religijnego. Wątpienie powraca jednak $\mathrm{u}$ większości wierzących w ich religijną postawę, ponieważ ryzyko zaufania religijnego nie zostaje pokonane raz na zawsze. Pozostaje ono nadal wysiłkiem i ryzykiem, dlatego pasowanie się między wątpieniem a oddaniem się w wierze nie ustaje. Bywa jednak i tak, że wątpienie to może przybrać rozmiary uniemożliwiające sam akt religijnego zaangażowania. Na obecność wątpienia w religijności wpływa także to, że konflikt między wierzeniem i odmową wierzenia jest dość powszechnym stanem umysłu u człowieka. Jego nasilenie bywa różne. Przybiera formę i sposób funkcjonowania w zależności od osobowości i funkcji, jaką w niej spełnia u poszczególnej jednostki ${ }^{7}$.

G. W. Allport rozważa problem zwątpienia w kontekście religijnej wiary i niewiary. Wiara jest wg niego zgodą na afirmację, jaką odczuwamy w odniesieniu do istnienia obiektu religijnego. Niewiara jest negatywną, odrzucającą. reakcją lub postawą i zwykle następuje wtedy, kiedy doświadczenie jednostki

\footnotetext{
${ }^{6}$ Por. W. Szewczuk (red.), Stownik psychologiczny, Warszawa 1979, s. 15; A. Podsiad, Z. W i ęc k ow s ki, Mały stownik terminów i pojęć filozoficznych, Warszawa 1983, s. 419.

7 G. W. Allport, Osobowość i religia, Warszawa 1988, s. 183; L. D u prè, Inny wymiar, Kraków 1991, s. 47 nn.
} 
przeciwstawiało się pierwotnemu impulsowi, aby wierzyć temu, co zostało podane przez zmysły lub słownie. Zwątpienie, podobnie jak niewiara, jest więc według Allporta wtórnym stanem życia umysłowego. Jest to zmienna, chwiejna reakcja wywołana kolizją oczywistości z wcześniejszym wierzeniem albo jednego wierzenia $\mathrm{z}$ drugim. Zwątpienie jest stanem niepewności spowodowanym kolizją przekonań z przeciwnymi im faktami lub przekonaniami. Zwątpienie jest stanem mniej ostatecznym niż niewiara, lecz bardziej złożonym. Wypływa jednak z tych samych psychologicznych źródeł ${ }^{8}$.

W religijności jednostki przez całe życie odbywa się integracja poznanych faktów (niewysłuchane modlitwy, kolizja wiary z realiami życia, brak cudów) z niedojrzałymi wyobrażeniami i poglądami religijnymi czy z uczuciową warstwą religijności. Trudno jest dopasować osobiste dylematy jednostki pochodzące z jej doświadczeń, potrzeb i aspiracji, mających zindywidualizowany charakter, do schematów religijnego myślenia i zachowania obowiązujących w rodzinie, Kościele czy u uznanych autorytetów religijnych. Prawie każdy moment życia pociąga możliwość wyboru różnych potencjalnych przekonań.

Cechą charakterystyczną zwątpienia jest to, że atakuje wyższe szczeble rozumienia. Nie jest trudno przyjąć jakieś fakty, gdy dają się sprawdzić ogólnie przyjętymi sposobami weryfikacji. Ale w zakresie ich wyjaśniania, oceny czy określenia ich szerszej wartości kierunki interpretacji u poszczególnych ludzi rozchodzą się. Dzieje się tak, ponieważ religia jest złożoną rzeczywistością, najbardziej nieuchwytną ze wszystkich dziedzin umysłowego poznania, a więc i najbardziej kontrowersyjną, dążącą do powiązania faktów, wartości z rzeczywistością ostateczną.

Występowanie zwątpienia w religijności nie jest zarezerwowane dla jednego okresu życia. Krótkotrwałe okresy zwątpienia mogą występować już w dzieciństwie $^{9}$. W okresie dorastania wątpienie jest związane z odkrywaniem własnego świata wewnętrznego i ma silnie afektywną postać. Jego źródłem jest poszukiwanie własnej niezależności (autonomii) przez wyparcie się dotychczasowych autorytetów, w tym i religijnego z racji jego związku z moralnością. Wątpienie może po części pochodzić z przechodzenia od dziecięcego fideizmu do personalnego uznania Boga, częściowo także z intensywnych niepokojów erotycznych prowadzących do konfliktu z normami moralnymi. Jeszcze innym źródłem religijnych wątpliwości jest ogólny kryzys zaufania (poczucie osamotnienia, lęku, absurdalności życia) pociągający także zgeneralizowaną próżnię uczuciową. Wątpliwości religijne zanikają, gdy dorastająca jednostka dokona wyboru na podstawie własnej myślowej syntezy świata ${ }^{10}$.

${ }^{8}$ G. W. Allport, jw., s. $183-193$.

${ }^{9}$ Por. J. L. Kli n k, Wierzyć z dziećmi, Warszawa 1989.

${ }^{10}$ Por. A. Vergote, Psicologia religiosa, Roma 1979, s. $305-309$; L. B. B row n, Psychology of Religious Belief, London 1987, s. 193. 
W wieku dojrzałym pojawiające się wątpienie posiada bardziej intelektuaIny charakter. Może ono też przyjąć formę egzystencjalnego dylematu między wyborem Boga a Jego odrzuceniem. J. Kozielecki określa go jako „dylemat alfa" twierdząc, że występuje on u każdej jednostki przynajmniej raz w ciągu życia. Zawiera on składniki psychologiczne, filozoficzne i transcendentne. Dylemat ten wyraża rozwój osobowości i ekspresję wolności woli jednostki. Warunkiem jego zaistnienia jest zdolność jednostki do myślenia abstrakcyjnego i syntetycznego, do przekraczania tego, kim jest i co posiada. Jest on bardzo złożony i zawiły. Czas podejmowania egzystencjalnej decyzji w religijności może trwać latami, a w pewnych okolicznościach stan abulicznego niezdecydowania może trwać bez końca. Dylemat wyboru „z Bogiem albo bez Boga” najczęściej pojawia się w momencie jakiegoś kryzysu osobistego czy społecznego, gdy jednostka czuje całą absurdalność życia. Tak Cruchon, jak i Kozielecki, jako ilustrację takiego dylematu podają wypowiedź św. Augustyna z Wyznań: „Wnętrze mojej istoty przestało być spokojnym domem [...]. Gdy usiłowałem podjąć decyzję służenia Panu, Bogu mojemu, zgodnie z żywionym od dawna zamiarem, ja sam byłem tym, który chciał, jak też ja sam byłem tym, który nie chciał [...]. Ale ani nie podejmowałem tej decyzji, ani jej nie odrzucałem pełnię swojej woli. Przeto spierałem się z sobą i sam roztrwoniłem swoje siły"11.

Dylemat egzystencjalny, który mobilizuje najczęściej całego człowieka, gdyż dotyczy jego najwyższej, centralnej wartości, wywołuje rezonans we wszystkich sferach jego funkcjonowania. Nie została bowiem „dopuszczona do głosu”, bądź została zanegowana, zdewaluowana bądź odsunięta na plan dalszy istotna dla jego rozwoju wartość. „Człowiek psychiczny” buntuje się przeciw „człowiekowi duchowemu” w tym samym podmiocie, gdyż pewien ideał humanistyczny staje na przeszkodzie ideałowi religijnemu wyższego stopnia ${ }^{12}$.

Przyczyną zwątpień, ambiwalencji, dylematów może być struktura osobowości jednostki. Na dziedzinę religijną przenoszone są takie jej cechy jak: nadmierna dociekliwość i chęć rozumienia wszystkiego, podejrzliwość, nieufność, neurotyczne poczucie niepewności. Trudności mogą też wynikać z niskiego poziomu wiedzy religijnej. Religijność ambiwalentna może pochodzić z braku wierności przyjętym zasadom życia religijnego i moralnego (grzech) oraz z zaniedbywanej więzi z Transcendencją. Gdy źródło wątpienia ma charakter ściśle ponadpsychologiczny, wtedy jednostka doświadcza intensywnie nieobecności Boga w swoim życiu religijnym, w poczuciu utraty Boga a nawet odrzucenia $^{13}$.

Każda jednostka ma swoją własną historię, wzorzec i stopień religijnych konfliktów, niemniej istnieją pewne rodzaje zwątpienia częściej spotykane

${ }^{11}$ Por. G. Cruchon, jw., s. 303; J. Kozieleck i, Z Bogiem albo bez Boga. Psychologia religii: nowe spojrzenie, Warszawa 1991, s. 47 - 49.

${ }^{12} \mathrm{G}$. Cruch on, jw., s. 303.

${ }^{13}$ Z. Płuże k, Psychologia pastoralna, Kraków 1991, s. 126. 
i wykazujące podobieństwo do występujących u innych ludzi. Zdarza się też często, że jednostka żywi kilka rodzajów religijnego konfliktu. Najczęściej spotyka się następujące jego formy ${ }^{14}$ :

1. Ambiwalencja w odniesieniu do elementów systemu doktrynalnego. Jest ona rozpowszechniona w różnego typu wątpliwościach. Jest to konflikt między dającymi się przyjąć normami dowodowymi a jakąś specyficzną treścią religijnej doktryny. Pochodzi $\mathrm{z}$ niezrozumienia języka formułowanych w nauczaniu prawd, który zamiast wzbudzać intencję religijną u podmiotu i właściwie ją na rzeczywistość transcendentną kierować, zatrzymuje uwagę na treści towarzyszącej religijnemu odniesieniu.

2. Ambiwalencja o charakterze reaktywnym i negującym. Może być ona odzwierciedleniem nieświadomej postawy jednostki wobec ojca, albo następstwem jakiegoś traumatycznego przeżycia, którego nie potrafi ona pogodzić z dotychczasowym życiem religijnym. Przy zwątpieniu negującym jednostka występuje przeciwko formalnej religii z obawy zahamowania przez nią swobody umysłu. Reaktywni wątpiący często podtrzymują najwyższą normę etycznego postępowania, wykazując jednocześnie podejrzanie głębokie zainteresowanie religią.

3. Ambiwalencja pod wpływem niedoskonałości i błędów religii instytucjonaInej. Kościół jest spostrzegany jako skomercjalizowana instytucja usług religijnych, strzegąca zakazów i nakazów przeznaczonych do ograniczania swobody myśli i postępowania. Prowadzi to do dużego natężenia emocji i każe myśleć, że zło w imię religii zdaje się przewyższać zło, do jakiego są zdolni ludzie niereligijni. Często wiąże się to z postawą antyklerykalną, której ideologia służy redukcji neurotycznego niepokoju i poczucia winy (,nerwica eklezjogenna"). Jednostki antyklerykalne wykazują psychologiczne podobieństwo do mlodocianych przestępców manifestujących swoje wrogie uczucia do rodziców, przez których chcieliby być lepiej rozumiani w swoich słusznych aspiracjach.

4. Ambiwalencja na skutek doświadczenia nieskuteczności wiary dla zaspokajania własnych potrzeb („Religia nie zapewnia mi egzystencji”). Religijność jednostki ukształtowana egomorficznie słabnie, gdy przestaje służyć bezpośrednio interesowi jednostki w jej własnym rozumieniu.

5. Ambiwalencja w następstwie odkrycia pozareligijnej genezy własnej religijności. Następuje ona, gdy jednostka odkryje dyskusyjną wartość motywów własnej religijności, które okazują się niedojrzałe, uformowane dla zaspokojenia egocentrycznych potrzeb lub pod presją środowiska. Jest to częsty rodzaj zwątpienia, gdyż wykształcony człowiek nie chce być oszukiwany przez zdemaskowane przez siebie mechanizmy samooszukiwania się.

${ }^{14}$ Uporządkowanie różnych form ambiwalencji w religijności zostało opracowane w oparciu o następujące pozycje: G. Cruch on, jw., s. 302-313; V. E. Frank1, Nieuświadomiony Bóg, Warszawa 1978, s. $56 \mathrm{nn}$; G. W. All port, jw. 
6. Ambiwalencja sceptyków. Jednostka niezdolna do przyjęcia religijnych treści budzących w niej niepokój, do przezwyciężenia konfliktu między ego i wymaganiami religijnymi wytwarza pewien "dystans” między ego a religijnymi obiektami, których się obawia, a których nie potrafi usunąć z pola swojej świadomości. Obiekty oddalone np. przez śmiech, zmniejszają poczucie lęku. Możliwość ironizowania służy silniejszemu rozładowaniu emocji. Ambiwalencja taka przekształca się niekiedy w sceptycyzm, jeśli te napięcia nie są pokonywane, gdy korzystania z przyjemności jednostka nie podporządkuje normom moralnym czy religijnym.

7. Ambiwalencja u humanistów jest efektem redukcjonistycznego podejścia do religii. Zaburzenie wiary pochodzi u jednostki ze spostrzegania zmian w rozumieniu Boga i religii w zależności od potrzeb bytu i kultury człowieka. Zmiany w religijnym rozumieniu ludzkiej historii wg jednostki dowodzą jedynie intensywności ludzkich wysiłków w poszukiwaniu bóstwa.

8. Ambiwalencja u żyjących w stanie duchownym pochodzi często ze zderzenia nieaktualnej koncepcji swego powołania (roli) z nową wizją świata i człowieka czy z utratą poczucia własnej tożsamości. W konflikcie jest tendencja do przyjmowania roli świeckiego chrześcijanina przy zagubieniu sensu czynności sakralnych z tendencją do zachowania transcendentnego charakteru swego życia przez oddzielenie się od ludzi, widzianych jako mniej wartościowych i zamkniętych na treść i sposób życia jednostki przeżywającej swe zwątpienie.

9. Ambiwalencja uwarunkowana posiadaną koncepcją Boga. Prawie zawsze u źródeł problemów religijnych znajduje się ukształtowana subiektywnie postać Boga w jej wymiarach: emocjonalnym i poznawczym. Ambiwalentna religijność może być uwarunkowana przeniesieniem ambiwalentnego stosunku emocjonalnego z rodzicami na stosunek do Boga, niezdolnością do zharmonizowania przeciwstawnych sobie postaci rodzicielskich i boskiej. Brak połączenia między przeciwstawnymi atrybutami przedmiotu religijnego wprowadza ambiwalencję wyrażającą się w negacji Boga i religii z częstym powracaniem do tych kwestii.

10. Ambiwalencja pod wpływem konfliktu myślenia naukowego i religijnego. Do właściwości mýślenia naukowego należą: zainteresowanie wybranym sektorem rzeczywistości, nieemocjonalny i bezosobowy stosunek do rzeczywistości (obiektywizm), zawodowe wątpienie i dystans. U jednostki z taką mentalnością, której wystarczają sankcje naukowe dla etyki, wskutek limitowania rzeczywistości, niewrażliwości na resztę życia i nie pogłębiania wiedzy religijnej ustala się „akademicki dystans” do religii. Żródłem wątpienia jest także to, że dla potwierdzenia pewników myślenia religijnego nie wystarcza, tak jak to jest w nauce, ograniczona liczba faktów. System religijny ma bowiem więcej do sprawdzenia, a wiara musi umieścić całą serię konkretnych wydarzeń w porządku moralnym, estetycznym, 
kosmologicznym i włączyć czynnik osobowy, który nauka wyłącza, oraz zwieńczyć tę całość integrującą teologią. Dlatego nawyki myślowe, wymogi i oczekiwania właściwe kryteriom nauki i religii zdają się jednostce nie do pogodzenia. Jednym z następstw nieumiejętności dokonania właściwej syntezy jest przyjmowanie w pewnych okolicznościach pewników naukowych a w innych religijnych.

11. Ambiwalencja w następstwie odrzucenia zasad religii bądź utraty wiary. Ponieważ rzadko takie odrzucenie jest ostateczne, dlatego jednostka z trudem uwalnia się od personalnego poczucia winy. Grzech jest bowiem nie tylko zakłóconym stanem psychicznym, lecz odmową lojalności, błędem osobistym, a to wytwarza niepokój i pociąga dystans w kontakcie z Transcendencją. Stłumiona religijność może się wyłaniać od czasu do czasu w postaci wyraźnych objawów nerwicy, co zdradza, że „separacja serca” nie nastąpiła do końca mimo przeprowadzenia „rozwodu”. „Rozumem jestem oczywiście niewierzący, ale uczuciem może jednak wierzę" - mówił jeden z pacjentów V. E. Frankla.

12. Ambiwalencja w trakcie kryzysów natury duchowej (religijnej). W sytuacji głębokiego kryzysu na drodze duchowego rozwoju w kontakcie z Transcendencją, jednostka doświadcza intensywnego pasowania się elementu psychologicznego z ponadpsychologicznym. Podobnie jest w pewnych stanach religijnego nawrócenia, gdy jednostce z trudem przychodzi oderwać się od sposobu myślenia, postaw i nawyków, do których jest jeszcze przywiązana, dla okazania wierności nowym doświadczeniom w swojej relacji z Bogiem dopóki ten nowy wybór nie zacznie przynosić satysfakcji. Walka, podobnie jak u św. Augustyna, nie odbywa się między dwoma strukturami psychiki, lecz między chceniem psychologicznym i ponadpsychologicznym, „wolą cielesną” i ,wolą duchową". Ambiwalencję taką mogą przedłużać pewne źle zintegrowane struktury osobowości. Muszą one odpowiednio dojrzeć, aby osoba dała się prowadzić rzeczywistości ponadpsychologicznej.

Powyższa analiza problemu ambiwalencji w obszarze religijności jednostki ukazuje, że religijne konflikty przybierają bardzo zróżnicowaną formę i obejmują szeroki zakres zjawisk psychicznych konstytuujących religijność. Ambiwalencja ta dotyczy tak psychologicznej jak i ponadpsychologicznej płaszczyzny życia religijnego jednostki. Konflikty w relacji z przedmiotem religijnym znajdują swój wyraz w strukturze psychicznej, i odwrotnie, ta struktura i jej geneza stają się czynnikami determinującymi formę religijnej ambiwalencji.

Ambiwalentna postawa religijna zawiera w sobie połączenie tendencji do akceptowania i nieakceptowania pewnych twierdzeń systemu religijnego, przeciwstawnych uczuć względem przedmiotu religijnego oraz tendencji do 
podejmowania niespójnych działań wobec tego przedmiotu ${ }^{15}$. Religijność ambiwalentną konstytuują więc w dużej mierze konflikty w sferze myślenia religijnego (wątpienie), współwystępujące przeciwstawne emocje w stosunku do religijnego obiektu, dylematy woli (chcenie i nie chcenie jednocześnie) i decyzje związane z wyborami na rzecz przedmiotu, oraz niespójne zachowania.

Ambiwalencja religijna może przyjmować różną formę, w zależności od przewagi zaangażowanych w nią sfer psychiki jednostki i stopnia uświadomienia sobie przez nią konfliktu. Można przypuszczać, że ambiwalentny charakter religijności jest związany z kształtem i znaczeniem nadawanym wyobrażeniom, przekonaniom, oczekiwaniom czy obawom bardziej lub mniej skonkretyzowanym w stosunku do przedmiotu religijnego oraz, że da się ustalić osobowościowe czynniki funkcjonowania religijności ambiwalentnej ${ }^{16}$. Relację z próby weryfikacji ostatniej tezy stanowi dalszy ciąg tego artykułu.

\section{BADANIA WŁASNE}

\section{Strategia badań}

A. Prezentacjazmiennych:

a. Religijność ambiwalentna w wyżej określonym znaczeniu, której istotę stanowi konflikt motywacyjny.

b. Motywacyjne elementy struktury osobowości:

1) Potrzeby, jako hipotetyczne siły, dynamizmy, instynkty, motywy nadające zachowaniu jednostki energię i kierunek, które są jednocześnie cechami osobowości i elementami jej struktury.

2) Wartości rozumiane jako procesy oceniania i wyboru, kwalifikowania i uznawania czegoś za wartościowe, albo jako doświadczanie emocjonalne i przeżywanie wartości.

B. Hipoteza:

Przewiduje się, że konflikt motywacji religijnej w religijności ambiwalentnej jest zależny od struktury potrzeb psychicznych i od uznawanej hierarchii wartości.

C. Metody:

a. Wyodrębnienie grup - Skala samooceny religijności. Badania przeprowadzone zostały w latach 1987 - 1988 na terenie Elbląga, Gdańska, Gliwic, Krakowa, Nysy, Ostrowca i Warszawy. Przebadanych zostało 300 osób w wieku od 25 do 45 lat, $z$ wykształceniem przynajmniej średnim. Każda z badanych osób oceniła swój stosunek do religii na następującej skali:

${ }^{15}$ Analogicznie do komponentów postawy religijnej pozytywnej; por. W. Prężyna, Skala postaw religijnych, „Roczniki Filozoficzne” 16 : 1968 z. 4 s. $75-89$.

${ }^{16}$ Por. J. M. J a s pa rd, Composantes psychologiques d'une maturation de la foi cretienne. „La foi et les temps" 1: 1973 s. $3-25$. 
1. zdecydowanie wierzący, 2. wierzący, 3 . raczej wierzący, 4 . wątpiący, ale zainteresowany sprawami wiary, 5 . obojętny na te sprawy, 6 . raczej niewierzący, 7. niewierzący, 8. zdecydowanie niewierzący.

Grupę eksperymentalną (A) stanowią osoby, które w samoocenie religijności zakreśliły cyfrę $4(\mathrm{~N}=30)$, a więc zadeklarowały się jako „wątpiący, ale zainteresowani sprawami wiary". Wydaje się, że autodeklaracja religijna podobnie jak samoocena w osobowości - spełnia funkcję centralnego wyznacznika równowagi w religijnym zachowaniu. Dlatego wybrano ją dla wyodrębnienia grup badawczych. Do grupy kontrolnej (K) włączono osoby, które oceniły siebie jako „zdecydowanie wierzący” $(\mathrm{N}=112)$. Obie grupy nie różnią się istotnie w zakresie zmiennych: płci, wieku i wykształcenia.

b. Techniki badania zmiennych osobowości

1) Wskaźnik Upodobań (WU) - G. G. Sterna

Metoda została opracowana do badania struktury potrzeb na bazie klasyfikacji potrzeb przeprowadzonej przez H. A. Murraya. Wg Sterna potrzeba posiada charakter funkcjonalny - reprezentuje cele albo zamiary, których współwystępowanie służy dobru jednostki. O jej istnieniu wnosi się na podstawie analizy interakcji zespołu zachowań charakteryzujących jednostkę. Źródłem możliwych zachowań są wszystkie konkretne sytuacje życiowe. Test ten posiada wystarczająco wysokie współczynniki trafności i rzetelności obliczone tak na populacji amerykańskiej jak i polskiej ${ }^{17}$. W kwestionariuszu uwzględnia się 42 potrzeby wyodrębnione przez Murraya.

2) Preferencja Wartości $(P W)$ - M. Rokeacha

Wartość według Rokeacha jest trwałym przekonaniem, że ostateczny stan egzystencji oraz określony sposób postępowania jest osobiście lub społecznie preferowany w stosunku do alternatywnego sposobu postępowania lub ostatecznego stanu egzystencji.

Wartości terminalne (ostateczne) określają stan finalny ludzkich dążeń, przekonanie, że cel ten jest personalnie lub społecznie wart najtrudniejszych zabiegów czy walki. Mogą one mieć charakter osobisty lub społeczny.

Wartości instrumentalne (użytkowe) są rozumiane jako sposoby osiągania wartości ostatecznych. Dzielą się na wartości moralne i kompetencyjne.

Badania przeprowadzono skalą $\mathrm{w}$ wersji $\mathrm{E}$, w autoryzowanym tłumaczeniu J. Łuckiego. Jest to lista 18 wartości terminalnych (WT) i 18 wartości instrumentalnych (WI). Walory statystyczne testu zostały sprawdzone, tak w jego wersji amerykańskiej jak i polskiej ${ }^{18}$.

${ }^{17}$ G. G. Ste r n, Preliminary Manual. Activity Index. College Characteristics, New York 1958. W języku polskim na ten temat m.in.: W. Pręży na, Potrzeby jako korelaty postawy religijnej, „Roczniki Filozoficzne” 24: 1976 z. 4 s. 5-28; S. Si e k, Wybrane metody badania osobowości, Warszawa 1983 , s. $108-145$.

18 Por. M. Rok e a ch, Value System in Religion, „Review of Religious Research” 11 : 1969 s. 3 - 23. Wszystkie dane na temat metody można znaleźć m. in. w: P. B r zozow s ki, Skala wartości - polska wersja testu Miltina Rokeacha, [w:] R. L. D rw al (red.), Techniki kwestionariuszowe $w$ diagnostyce psychologicznej. Wybrane zagadnienia, Lublin 1989, s. 81 - 124. 


\section{Wyniki}

A. Struktura potrzeb.

Za pomocą testu parametrycznego $t$ Studenta porównane zostały średnie wyniki grupy ambiwalentnej i kontrolnej w zakresie 42 potrzeb ze $W U$ Sterna. Tabela 1. zawiera średnie wyniki $(M)$, odchylenia standardowe $(S D)$, wartość $t$ oraz poziom istotności dla tych skal, w których między porównywanymi grupami występują istotne różnice.

Tabela 1. Średnie wyniki grupy ambiwalentnej i kontrolnej w zakresie skal WUSterna, w których wystąpiły różnice istotne

\begin{tabular}{|l|c|c|c|c|c|c|}
\hline \multirow{2}{*}{\multicolumn{1}{|c|}{ POTRZEBA }} & \multicolumn{2}{|c|}{ GR. AMB. (N=30) } & \multicolumn{2}{c|}{ GR. KONTR. (N=112) } & \multirow{2}{*}{$t$} & \multirow{2}{*}{$p . i}$. \\
\cline { 2 - 5 } & $M$ & $S D$ & $M$ & $S D$ & & 0.05 \\
\hline humanizmu & 3.8 & 2.15 & 4.7 & 2.49 & 2.00 & 0.01 \\
opiekuńczości & 5.3 & 2.41 & 6.7 & 3.56 & 2.58 & 0.05 \\
oparcia & 6.9 & 1.99 & 7.7 & 1.82 & 2.08 & 0.05 \\
samowystarczalności & 3.1 & 1.99 & 2.3 & 1.82 & -2.06 & 0.05 \\
osob. osiągnięć & 1.9 & 2.16 & 2.9 & 2.53 & 2.13 & 0.01 \\
agresji & 5.2 & 1.89 & 4.0 & 2.35 & -2.92 & 0.08 \\
porządku & 5.7 & 2.20 & 4.8 & 2.66 & -1.78 & \\
\hline
\end{tabular}

Wyniki przedstawione w tabeli 1 informują, że osoby z religijnością ambiwalentną różnią się istotnie od osób z religijnością zdecydọaną w zakresie sześciu spośród 42 potrzeb $W U$ Sterna: humanizmu, opiekuńczości, oparcia, samowystarczalności, osobistych osiągnięć i agresji.

Osoby ambiwalentne mają silniejsze potrzeby:

- a gresji, która wyraża się w jawnej lub ukrytej wrogości wobec innych, pokonywaniu sprzeciwu przy użyciu siły fizycznej lub psychicznej; także w poniżaniu, oskarżaniu, wyszydzaniu lub fizycznym atakowaniu innych osób;

- sa mow y st a rczaln ości, wyrażającej się w przeciwdziałaniu przymusowi, unikaniu i porzucaniu czynności nakazanych przez osoby autorytatywne, w uznawaniu prawa do niezależności w działaniu;

- porządku, wyrażającej się w organizowaniu bezpośredniego otoczenia fizycznego, w trosce o czystość, porządek w najdrobniejszych sprawach; osoby ambiwalentne w porównaniu ze zdecydowanymi religijnie mają mniej intensywnie rozwinięte potrzeby:

- humanistycznego poznania, przejawiającego się w zainteresowaniu zagadnieniami społecznymi, politycznymi czy historycznymi, a także dziedziną kultury i sztuki;

- opie kuńczości, która wyraża się w okazywaniu sympatii i pomocy wobec osób bezradnych, słabych i samotnych, dzieci, w ratowaniu osób znajdujących się w niebezpieczeństwie, niesieniu pomocy, wspieraniu, ochranianiu, pielęgnowaniu, leczeniu; 
- opa rcia, szukania pomocy przyjaznej osoby, miłości, opieki;

- osobistych osiągnięć, dążenia do osobistych sukcesów, wysoki poziom aspiracji (wola mocy), do zyskania wpływowej pozycji.

B. Hierarchia wartości.

Srednie wyniki grupy ambiwalentnej i eksperymentalnej uzyskane w tekście Preferencja Wartości Rokeacha porównano za pomocą nieparametrycznego testu $U$ Manna Whitneya i testu $W$ sumy rang Wilcoxona ${ }^{19}$.

a. Wartości terminalne:

Tabela 2. Różnice między średnimi wynikami grupy ambiwalentnej

i kontrolnej w zakresie preferencji WT Rokeacha

\begin{tabular}{|l|c|c|c|c|}
\hline \multirow{2}{*}{ WARTOŚCI } & \multicolumn{2}{|c|}{ RANGI OKREŚLONEJ WARTOŚCI } & & \multirow{2}{*}{ p.i. } \\
\cline { 2 - 3 } & GR. AMBIWAL. & GR. KONTROLNA & $z$ & - \\
\hline Bezpieczeństwo narodowe & 64.7 & 73.3 & -1.02 & - \\
Miłość dojrzała & 71.8 & 71.4 & -0.04 & - \\
Mądrość & 71.4 & 71.5 & -0.02 & - \\
Pięknoświata & 80.4 & 69.1 & -1.33 & - \\
Pokój na świecie & 63.7 & 73.6 & -1.17 & - \\
Przyjaźń prawdziwa & 69.5 & 72.0 & -0.30 & - \\
Przyjemność życia & 47.9 & 77.8 & -3.56 & - \\
Równość ludzi & 68.6 & 72.3 & -0.43 & - \\
Sukcesy życiowe & 60.9 & 74.3 & -1.60 & - \\
Szacunek dla siebie & 73.9 & 70.8 & -0.37 & - \\
Uznanie społeczne & 56.8 & 75.4 & -2.21 & 0.05 \\
Harmonia i wewn. spokój & 83.9 & 68.2 & -1.87 & - \\
Wolność osobista & 64.2 & 73.5 & -1.10 & - \\
Wygodne życie & 55.9 & 75.7 & -2.37 & 0.01 \\
Rodzina & 66.9 & 72.7 & -0.70 & - \\
Zbawienie & 115.9 & 59.6 & -6.95 & 0.00001 \\
Zdrowie & 68.9 & 72.2 & -0.39 & - \\
Życie pełne wrażeń & 69.7 & 72.0 & -0.27 & - \\
\hline
\end{tabular}

$\mathrm{Z}$ tabeli 2. wynika, że grupa ambiwalentna na czele hierarchii WT umieszcza kolejno: Przyjemność życia — bez nadmiernego pośpiechu, wg upodobań (0.01), Wygodne życie — dostatnie życie (0.01), Uznanie społeczne - szacunek i uznanie in. (0.05) oraz Sukcesy życiowe — trwałe zasługi, Pokój na świecie - świat wolny od wojen i konfliktów, Zabezpieczenie bytu dla rodziny troska o najbliższych. Grupa ta na samym końcu stawia Zbawienie — być zbawionym, życie wieczne (0.00001).

Dla porównania w grupie kontrolnej naczelnymi wartościami są: Zbawienie, Wewnętrzny spokój i harmonia, Piękno świata, Szacunek dla siebie,

${ }^{19} \mathrm{Na}$ temat obu zastosowanych testów statystycznych: J. P. Guilf ord, Podstawowe metody statystyczne w psychologii i pedagogice, Warszawa 1964. 
Dojrzała miłość, Mądrość, podczas gdy dopiero na końcu znajdują się wartości wiodące u osób ambiwalentnych: Przyjemność życia i Wygodne życie.

b. Wartości instrumentalne

Tabela 3. Różnice między średnimi wynikami grupy ambiwalentnej i kontrolnej w zakresie prefencji WT Rokeacha

\begin{tabular}{|l|c|c|c|c|}
\hline \multirow{2}{*}{ WARTOŚCI } & \multicolumn{2}{|c|}{ RANGI OKREŚONEJ WARTOSCI } & & \multirow{2}{*}{ p.i. } \\
\cline { 2 - 3 } & GR. AMBIWAL. & GR. KONTROLNA & & - \\
\hline Ambicja & 68.0 & 72.5 & -0.54 & - \\
Czystość & 70.0 & 72.0 & -0.24 & - \\
Gotowość kochania & 78.1 & 69.7 & -0.99 & - \\
Grzeczność & 75.7 & 70.4 & -0.63 & - \\
Logiczność myślenia & 66.5 & 72.8 & -0.75 & - \\
Lojalność & 73.7 & 70.9 & -0.33 & - \\
Odpowiedzialność & 65.9 & 73.0 & -0.83 & - \\
Odwaga & 64.2 & 73.5 & -1.10 & - \\
Opanowanie & 69.8 & 71.9 & -0.24 & - \\
Pomysłowość & 59.8 & 74.6 & -1.75 & - \\
Posłuszeństwo & 76.5 & 70.2 & -0.75 & - \\
Refleksyjność & 72.8 & 71.1 & -0.19 & - \\
Samodzielność & 51.6 & 76.8 & -2.99 & 0.01 \\
Tolerancja & 70.9 & 71.6 & -0.08 & - \\
Uczciwość & 87.1 & 67.3 & -2.39 & 0.01 \\
Uczynność & 85.3 & 67.8 & -2.07 & 0.05 \\
Wyrozumiałość & 93.1 & 65.7 & -3.24 & 0.001 \\
Zdolność & 54.1 & 76.2 & -2.62 & 0.01 \\
\hline
\end{tabular}

Zgodnie $\mathrm{z}$ danymi zamieszczonymi w tabeli 3., w swej hierarchii wartości instrumentalnych jednostki ambiwalentne najwyżej stawiają: samodzielność — poleganie na sobie, samowystarczalność (0.01); zdolność — fachowość, skuteczność działania (0.01); pomysłowość — śmiałość, tworzenie pomysłów; odwaga - obrona własnych poglądów; odpowiedzialność - niezawodność, solidność; logiczność myślenia - konsekwencja, racjonalność (różnice nieistotne). Najmniej cenione są w grupie ambiwalentnej wartości moralne: wyrozumiałość - gotowość przebaczania innym (0.001); uczciwość — szczerość, prawdomówność (0.01); uczynność — praca dla dobra innych (0.05). Grupa kontrolna najbardziej preferuje: wyrozumiałość, uczciwość, uczynność, gotowość kochania, posłuszeństwo, grzeczność, lojalność. W grupie kontrolnej za najmniej ważne uznane zostały: samodzielność, zdolność, pomysłowość.

\section{Interpretacja wyników}

Wyniki przedstawionych porównań wskazują na istnienie zakładanego związku religijności ambiwalentnej z osobowością jednostki. Charakterystyka osobowości osób ambiwalentnych w zakresie wyróżniających je potrzeb i war- 
tości daje dość spójny obraz psychologiczny. Osoby ambiwalentne mają potrzebę wolności i niezależności w działaniu, potrzebę kierowania się własnymi impulsami i zachciankami, nie lubią jednak brania na siebie odpowiedzialności. Wyrażają też potrzebę agresywnych zachowań i troskę o dobrą opinię we własnych oczach. Obniżone są ich zainteresowania humanistyczne, zapotrzebowanie na więź z innymi tak w celach szukania oparcia jak i udzielania pomocy. Nie mają też wysokich aspiracji.

Z wyróżniającymi się u osób ambiwalentnych potrzebami korespondują dokonywane wybory w dziedzinie proponowanych wartości. Najwyżej cenione są wartości terminalne: przyjemność życia, wygodne życie, uznanie społeczne oraz sukcesy życiowe. Jednostki zapewniają sobie ich osiąganie przez preferowanie kompetencyjnych wartości instrumentalnych o charakterze osobistym, na czele z samodzielnością i zdolnością.

Całkowicie zdewaluowana jest ekstrapersonalna wartość: zbawienie. Podobnie nie są brane pod uwagę instrumentalne wartości o charakterze moralnym, takie jak: wyrozumiałość, uczciwość, uczynność.

Zweryfikowane zależności wydają się być zrozumiałe z punktu widzenia funkcjonowania religijności w osobowości. Wartości ostateczne preferowane przez jednostki ambiwalentne nie są zgodne ani z tymi, które preferują „empirycznie" tutaj dobrane jednostki o religijności zdecydowanej, ani z tymi, które zaleca religijny system. Te wartości, które religia zaleca w postaci Wartości Absolutnej, wartości prospołecznych czy wartości moralnych są dla osób ambiwalentnych bardzo odległe. Jeżeli się weźmie dodatkowo pod uwagę charakteryzujące jednostki ambiwalentne potrzeby, to psychologicznie i religijnie zrozumiały staje się konflikt motywów, wartości. Jednostki egocentryczne, samowystarczalne, dbające o samoaktualizację przy słabo rozwiniętych relacjach społecznych, mają prawdopodobnie utrudnioną autotranscendencję także w kierunku przedmiotu religijnego, która jest podstawą dla kształtowania się religijnego odniesienia ${ }^{20}$. Występujące zależności pomagają widzieć czynnik osobowościowy u źródeł wielu form religijnej ambiwalencji. Aby poznać ich naturę, potrzebne są jednak dalsze badania.

${ }^{20}$ Por. W. E. Con n, The Ontogenetic Ground of Value, „Theological Studies” 39: 1978 s. 313 -335 . 


\section{AMBIVALENT RELIGIOSITY AND PERSONALITY: NEEDS AND VALUES}

\section{Summary}

The problem of the ambivalent religiosity and its relevance to the structure of needs and a preference of values was described in this article. First it was discussed the conception of ambivalention in psychology and in religiosity, then its occurence and kinds. The occurence of conflicts in a cognition sphere, co-existence of opposed emotions, volitional dilemmas and incoherent behaviour in relation to the religious object is characteristic for ambivalent religiosity.

The group of the ambivalent religiosity persons: ,doubting, but interested in questions of religion" $(\mathrm{N}=30)$ was compared to a control group: ,emphatic faithful” $(\mathrm{N}=112)$ by means of Activities Index - G. G. Stern and Survey Values - M. Rokeach. It appears that the ambivalent persons in the comparison to the emphatic faithful ones have greater intensity of the following needs: Aggression and Autonomy, and they have slighter intensity of such values like: Humanism, Nurturance, Succordance, Ego Achievement.

In the sphere of terminal values, the ambivalent individuals prefer: A comfortable life, An exciting life, Social recognition, Sense accomplishment and Salvation is the last one. The values of Independence and Capability occupy the leading places from among the instrumental values, while the folloving: Forgiveness, Honesty, Helpfulness are on the final positions. The acquired findings confirm (significant level) the hipothesis that the ambivalent religiosity is connected with mentioned elements of the personality structure. 